\title{
UTILIZATION OF INDUSTRIAL WASTE IN THE CONSTRUCTION INDUSTRY
}

\author{
D. Rastogi ${ }^{1}$, Umesh Sharma ${ }^{2}$ \\ ${ }^{1,2}$ Civil department MITS Gwalior 474005, India, deepak_rstg_mits@yahoo.co.in ${ }^{1}$,Sharmaumesh729@gmail.com²
}

\begin{abstract}
Utilization of industrial waste in construction industry. This experimental work is an effort to try to develop the awareness \& importance of industrial waste management \& its utilization in productive manner among the people. In today's more environmentally-Conscious world, a more responsible approach to the environment is to increase the use of by-products of one industry which is disposed off as waste as raw material for some other industry. Developed countries have made rapid strides in the utilization of supplementary Cementitious material in cement \& concrete. Lack of awareness Consumer preferences, negatives marketing strategies \& Lot of miss-understanding among the people have impeded their utilization in our country. In this work I have chosen three industrial wastes for blending with Portland cement Viz. Fly ash, Blast furnace slag \& waste of glass industry. All these three waste after grinding properly were blended with ordinary Portland cement in different proportions. Then that of blended cement was tested for various properties of cements such as Fineness, Standard Consistency; Soundness, Setting time \& Compressive Strength. As all these three wastes in powder form are of cementitious materials, they are proved to be best when blended with Cement. I have got improved results related to most of the properties of cement as compared to that of ordinary Portland cement. All these wastes prove the slogans true that are "ash to cash" or "refuse to resource" \& "wastes to wealth". In our country annually huge quantities of wastes are produced by the industries. Instead of disposing off these wastes if they are utilized in such a manner then it will provide an eco-friendly Solution, simultaneously solving the problem of pollution. So such waste can be blended with Cement, is the step towards economy \& obviously towards progress of the nation.
\end{abstract}

Keywords: - fly ash, ground blast furnace slag, waste glass powder; experiments on blended cement with different proportions of wastes; cost comparison.

\section{INTRODUCTION}

\section{A. FLY ASH:-}

Fly ash is finally divided by product obtained from the combustion of pulverized coal in suspension fired furnaces of thermal plant or we can simply called it as waste residue from thermal power stations. There are 70 thermal power stations in our India. Waterpower projects are comparatively very less.

Our country produces about 80 M.T. of coal ash per annum in various coal based thermal power stations. The disposal of such a large quantity of ash involves substantial expenditure in addition to locking up valuable land adjoining the power stations used as dumping ground. In addition to substantial initial capital expenditure on the infrastructure for transportation of the ash from the power station to the dumping ground.

With targeted development programmed in the energy sector during $9^{\text {th }}$ plan period, the fly ash generation is expected to reach a level of over 110 M.T. per year by 200 AD; Which would require on estimated on 28300 hectares of lands just for dumping. As result; environmental planner are facing greater challenges in preventing the degradation of environment and land being cost by fly ash dumps around thermal power stations all over India. Up till now government has incurred lot of money over disposal of fly ash But dumping in ground is not an ECO-FRIENDLY solution. The ash dump pollutes the subsoil and renders the surrounding are unfit for cultivation.

The increase level of fly ash is linked to air, water and land pollution; Eroding structural surface, causing respiratory problems due to continued inhalation of the polluted air. For comparison, developed countries like U.K., Germany, France, Poland and China utilize heavily $60-70 \%$ of fly ash in their construction programmed. At present; India is one of the lowest among the country of the world in the ash utilization. Only $30 \%$ of ash is being utilized in some projects in India. In spite of serious and concerted effort made by Union Govt. and state government technology mission fly ash disposal and utilization, there is no significant improvement in effective and large scale utilization of fly ash.

No doubt we have a fly ash mission at the national level and large number of other institution are involved in prompting the use of flay ash. The accent appears to be on encouraging use of fly ash for making bricks, road fills etc. which do not 
generate volume usage. Unfortunately there is no focus on the need for generating concrete quality fly ash.

The thermal power plants contained that the ash is just a byproduct and that it is not one of three core activities to process and supply concrete grade fly ash. In the UK. For instance a pulverized fly ash processing and supply industry has emerged, separate from the cement industry.

\section{B. GROUND BLAST FURNACE SLAG}

Slag is a by-product of the steel and cast iron industries. Slag is produced in blast furnaces after producing the steel. In India, annual produced of slag is about 25 million tones. In India, out of this only $20 \%$ of slag is in utilization while in France and Germany $85 \%$ of total produced slag is being utilized. Ground granulated blast furnace slag has been used as a cementitious agent for concrete for more than 30 Year in foreign countries. In some countries, slag cement has main share of the market. In Netherlands, for instance slag cement with 60 to $70 \%$ of slag has a market share of about $60 \%$. In other countries like U.K.; the market share of slag cement is only minor but the use of Ground granulated blast slag as addition in the read mix industry is substantial. Blended cement with slag has been more extensively used in the Eastern Regions where slag is easily available from steel plants Of late there is increasing awareness of the benefits involved. Thus has led to the addition of such cement and slag in batching plant at the project site. Recent examples includes. Worli - bandra outfalls and Ennore port in Chennai. Typical mix consisted of $70 \%$ slag \& $30 \%$ cement. As per IS code, the slag constituent shall not be less than $25 \%$ nor more than $65 \%$ of the cement. However, the international practice is to permit much higher slag content; upto $95 \%$. But in common practice, 70 to $80 \%$ slag can be blended with cement. The slag is a byproduct of steel plants and as such as the cost of slag is definitely lower that the cost of ordinary Portland cement, even after accounting for the cost and transportation and grinding.

\section{GLASS WASTE POWDER}

This glass powder is the waste from glass factory.After manufacturing pure glass, residue and small pieces of glass is considered as glass waste. This waste also contains silica in large extent. Generally $85 \% \mathrm{SiO}_{2}$ content in the waste found to be satisfactory. As the silicon content of alloy increases, the $\mathrm{SiO}_{2}$.

On carbonation it is found that, silica is very highly reactive pozzolanic material and being very fine, can react very fast with $\mathrm{Ca}(\mathrm{OH})_{2}$ which is a by-product of cement with fly ash as third component it further gives benefit of pore refinement by microstructure modification.
A tertiary blend of OPC, silica with fly ash has been found to be a better combination than use of silica waste alone to improve carbonation resistance.

In our India , there are 43 glass factories at this stage. Among them, some of them are most reputed like Philips Lamps. All these industries produces different types of glass with various thickness. As compared to foam glass, lamp glass contains more silica.

Due to this large content of silica strengthens property is mostly developed in that glass.

Glass industries produces 22 M.T. of waste every year. Out of it near about 7 M.T. of waste utilizes for re-production of glass and 15M.T. of waste is going as waste. As silica possesses more strength, this waste of glass should be utilized. Ordinary Portland cement contains only $22 \%$ of silica whereas this waste contains $85 \%$ of silica.

So this waste may more strong if blended with OPC than that of plain O.P.C.

Cost saving was most probably the original reason for blending of cementitious material, like glass waste silica powder. And that's why silica powder is utilizing now a days.

\section{CASE STUDY}

\subsection{Materials:}

ASTM - C $618=93$ categorizes fly ashes into the following three categories:

1. Class N Fly ash: Raw or calcined natural pozzolans such as some diatomaceous earths, opaline chert and shale, stuffs, volcanic ashes and pumice come in this category. Calcined kaolin clay and laterite shale also fall in this category of pozzolans.

2. Class F Fly ash: Fly ash normally produced from burning anthracite or bituminous coal falls in this category. This class of fly ash exhibits pozzolanic property but rarely if any, selfhardening property.

3. Class C Fly ash: Fly ash normally produced from lignite or sub- bituminous coal is the only material included in this category. This class of fly ash has both pozzolanic and varying degree of self cementitious properties. (Most class $\mathrm{C}$ fly ashes contain more than $15 \% \mathrm{CaO}$. But some class $\mathrm{C}$ fly ashes may contain as little as $10 \% \mathrm{CaO}$. For testing work, industrial wastes which are used for blending with Portland cement are as given below with their sources : - 


\begin{tabular}{|c|c|c|}
\hline & Material & Source \\
\hline (1) & Pulverised fly ash & $\begin{array}{l}\text { Thermal Power Station } \\
\text { Dipnagar, } \\
\text { Tal. Bhusawal, } \\
\text { Dist, Jalgaon }\end{array}$ \\
\hline (2) & Blast Furnace slag & $\begin{array}{l}\text { ISPAT Steel Industries } \\
\text { Dharamtar }\end{array}$ \\
\hline (3) & Glass waste silica & $\begin{array}{l}\text { Taloja Glass industry } \\
\text { New Bombay }\end{array}$ \\
\hline
\end{tabular}

$\begin{array}{lll}\mathrm{Al}_{2} \mathrm{O}_{2} & - & 28.00 \% \\ \mathrm{MgO} & - & 8.50 \% \\ \mathrm{MnO} & - & 1.70 \% \\ \mathrm{~F}_{\mathrm{e}} \mathrm{O} & - & 1.70 \% \\ \mathrm{~S} & - & 0.90 \%\end{array}$

\subsection{Table showing all the result of the test}

For making blended cement, following proportions are preferred :-
(1) $50 \% \mathrm{OPC}+50 \%$ Waste
(2) $60 \% \mathrm{OPC}+40 \%$ Waste
(3) $40 \% \mathrm{OPC}+60 \%$ Waste

The effect on the properties using different proportions have been studied and tabulated.

\subsubsection{Chemical analysis of Fly Ash: - [ From} Dipnagar]

$\begin{array}{lll}\mathrm{SiO}_{2} & - & 60.20 \% \\ \mathrm{Al}_{2} \mathrm{O}_{2} & - & 18.45 \% \\ \mathrm{Fe}_{2} \mathrm{O}_{3} & - & 16.20 \% \\ \mathrm{MgO} & - & 1.02 \% \\ \mathrm{C}_{\mathrm{a}} \mathrm{O} & - & 2.00 \% \\ \mathrm{SO}_{3} & - & 1.00 \% \\ \mathrm{Na}_{2} \mathrm{O} & - & 1.00 \%\end{array}$

2.1.2 Chemical analysis of Glass Silica Waste:- [From Taloja Glass Industry]

$\begin{array}{lll}\mathrm{SiO}_{2} & - & 88 \% \\ \mathrm{SiO}_{3} & - & 3 \% \\ \mathrm{C}_{\mathrm{a}} \mathrm{O} & - & 1 \% \\ \mathrm{Mg}_{\mathrm{g}} \mathrm{O} & - & 2.5 \% \\ \mathrm{SO}_{3} & - & 1 \% \\ \mathrm{~S} & - & 2.8 \% \\ \text { Free C } & - & 1.7 \%\end{array}$

2.1.3 Chemical analysis of Blast Furnace Slag:- [ From ISPAT]

$\begin{array}{lll}\mathrm{SiO}_{2} & - & 30.50 \% \\ \mathrm{C}_{\mathrm{a}} \mathrm{O} & - & 29.50 \%\end{array}$

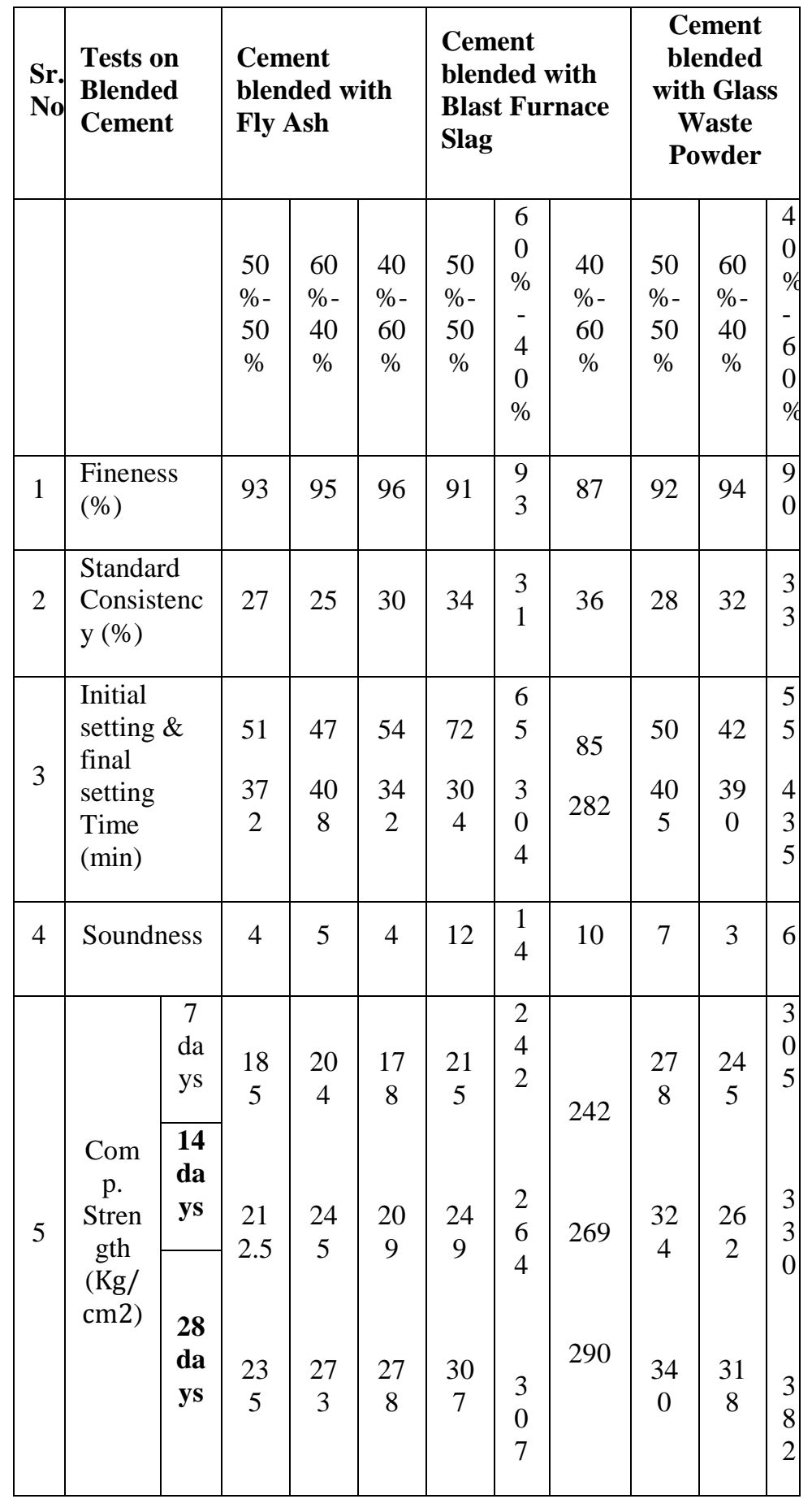



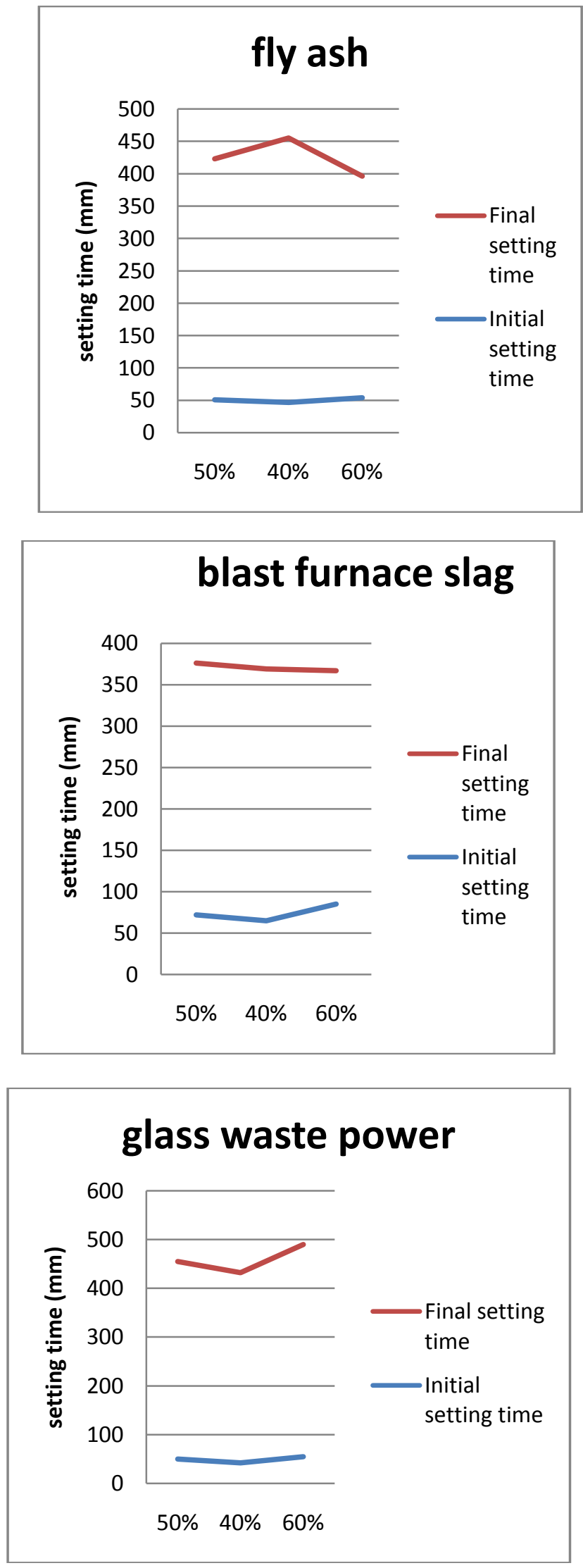

\section{COST COMPARISON}

Blended cement is definitely cheaper than ordinary Portland cement.

Blended cement can be made in different proportions of ordinary Portland cement with industrial wastes. As waste is useless and having no value, saving is to be seen clearly. Only transportation cost, we have to pay to for bringing waste from source to the manufacturing place from where we can bring it.

\begin{tabular}{|cc|l|}
\hline \multicolumn{2}{|c|}{ Wastes } & \multicolumn{1}{|c|}{ Source } \\
\hline (1) & Pulverised fly ash & $\begin{array}{l}\text { Thermal Power } \\
\text { station at Dipnagar. } \\
\text { Tal. Bhusawal, Dist. } \\
\text { Jalgaon }\end{array}$ \\
\hline (2) & $\begin{array}{l}\text { Ground blast } \\
\text { furnace slag }\end{array}$ & $\begin{array}{l}\text { ISPAT steel } \\
\text { industries, Dharamtar. } \\
\text { Alibagh }\end{array}$ \\
\hline (3) & $\begin{array}{l}\text { Glass waste silica } \\
\text { powder }\end{array}$ & $\begin{array}{l}\text { Taloja glass unit, New } \\
\text { Bombay }\end{array}$ \\
\hline
\end{tabular}

All the sources considered with study are from Maharashtra. In other states also similar sources for getting quality wastes might be available. But above sources are nearby with us so we have brought all the waste sample from there. For cost comparison between ordinary Portland cement and blended cement. We will consider $1 \mathrm{M}^{3}$ of concrete.

In blended cement, we will consider fly ash first Proportion of $50 \%$ of O.P.C. With 50\% 1st class F.A. is the best proportion among the all proportions tested by me.

For $1 \mathrm{M}^{3}$ concrete [1:2:4]

\begin{tabular}{|l|l|c|}
\hline \multicolumn{1}{|c|}{ Material } & & Qty. \\
\hline Cement & -- & $\begin{array}{c}0.22 \mathrm{M}^{3} \\
{[6.5 \mathrm{bags}]}\end{array}$ \\
\hline O.P.C. & -- & 3.25 bags \\
\hline F.A. & -- & $3.25 \mathrm{bags}$ \\
\hline Sand & -- & $0.44 \mathrm{M}^{3}$ \\
\hline Course Aggregate & -- & $0.88 \mathrm{M}^{3}$ \\
\hline
\end{tabular}

Cost comparison as per current rates 


\begin{tabular}{|c|c|c|c|c|c|c|c|c|c|c|c|}
\hline \multirow[t]{2}{*}{$\mathbf{S r}$} & \multicolumn{5}{|c|}{ O.P.C Concrete } & \multicolumn{3}{|c|}{$\begin{array}{c}\text { Blended Cement } \\
\text { Concrete }\end{array}$} & \multicolumn{3}{|c|}{ Remark } \\
\hline & $\begin{array}{c}\text { Ma } \\
\text { teri } \\
\text { al }\end{array}$ & Qty. & $\begin{array}{l}\mathrm{Ra} \\
\text { te }\end{array}$ & Per & $\begin{array}{c}\mathrm{Am} \\
\mathrm{t} .\end{array}$ & $\begin{array}{c}\text { Mat } \\
\text { eria } \\
1\end{array}$ & Qty. & Rate & Per & Amt. & \\
\hline \multirow[t]{2}{*}{ 1) } & $\begin{array}{l}\text { O.P } \\
. C\end{array}$ & $\begin{array}{l}0.22 \mathrm{M} \\
{[6.5}\end{array}$ & $\begin{array}{c}30 \\
0\end{array}$ & Bag & $\begin{array}{c}195 \\
0\end{array}$ & $\begin{array}{l}\text { O.P } \\
. C\end{array}$ & $\begin{array}{l}3.5 \\
\text { Bag }\end{array}$ & 300 & Bag & 1050 & \multirow{2}{*}{$\begin{array}{l}\text { F.A. from } \\
\text { thermal power } \\
\text { station } \\
\text { dipnagar }\end{array}$} \\
\hline & & bags] & & & & F.A & $\begin{array}{l}3.5 \\
\text { Bag }\end{array}$ & -- & - & -- & \\
\hline 2) & $\begin{array}{c}\text { San } \\
\text { d }\end{array}$ & $0.44 \mathrm{M}$ & $\begin{array}{c}28 \\
5\end{array}$ & $\mathrm{M}^{3}$ & 125 & $\begin{array}{c}\text { San } \\
\text { d }\end{array}$ & $0.44 \mathrm{M}$ & 285 & $\mathrm{M}^{3}$ & 125 & \\
\hline 3) & $\begin{array}{c}\text { Co } \\
\text { urs } \\
\mathrm{e} \\
\mathrm{Ag} \\
\text { gre } \\
\text { gat } \\
\mathrm{e}\end{array}$ & $0.88 \mathrm{M}$ & $\begin{array}{c}42 \\
5\end{array}$ & $\mathrm{M}^{3}$ & 374 & $\begin{array}{l}\text { C. } \\
\text { A. }\end{array}$ & $0.88 \mathrm{M}$ & 425 & $\mathrm{M}^{3}$ & 374 & \\
\hline & & Total & & $\mathbf{R s}$ & 2449 & & & To & & Rs. 1549 & \\
\hline
\end{tabular}

\section{For blended cement: -}

Transportation cost of F.A. from source to the site $=$ Rs. 90/[Rs. 500/Truck]

Total expenditure requires for making of $1 \mathrm{M}^{3}$ concrete with blended cement is

$$
\begin{aligned}
& \text { Rs. } 1549 \\
& +90 \\
& \text { Rs. 1639/- }
\end{aligned}
$$

Saving in the cost per $\mathrm{M}^{3}$ Concrete after using blended cement

$$
=\text { Rs. } 2449-1549
$$$$
=\text { Rs. } 900 /-
$$

Saving is the cost will be different at different places; depends upon distances of the sources of wastes.

\section{CONCLUSIONS}

After testing blended cement with different proportions, following conclusions are drawn:-

(1). Ist Class fly ash blended cement is more fine than that of the plain Portland cement. But IInd class and IIIrd class fly ash are not liable for blending as they are coarser.

(2). Standard Consistency of blended cement is comparatively less than that of ordinary Portland cement. It means that W/C. Ratio obtained is less than that of plain cement.

(3). Ground blast furnace slag proves to be best waste for blending with Portland cement as it increases initial setting time and decreases the final setting time of cement considerably. owever fly ash and glass waste blended cement are also good in this case.
(4). Fly ash based blended cement is comparatively more sound than that of the glass waste blended cement and also than that of plain cement. But slag based blended cement proved as unsound cement.

(5). In case of compressive strength, glass waste blended cement imparts more strength than that of the ordinary cement. So blended cement proved as improved material as compared to O.P.C in all the properties of cement. Blended cement is economical and Eco-friendly. There is lot of saving in energy consumption while manufacturing such cement.

\section{REFERENCES}

[1] Recommended guidelines of fineness of cement, IS 269:1976,Bureau of Indian Standards, New Delhi

[2] Method of tests for standard consistency of cement, IS 4031:1968, Bureau of Indian Standards, New Delhi.

[3] Initial setting time and final setting time of cement method of test, IS 269:1967/1975,Bureau of Indian Standards, New Delhi

[4] Compressive strength of cement method of test, IS 650:1969, Bureau of Indian Standards, New Delhi

[5] M.S. Shetty, "Concrete Technology Theory and Practice" S. Chand and Company Ltd., New Delhi, 2006.

[6] M.L. Gambhir, "Concrete Technology", Tata McGrawHill Publishing Company Limited, New Delhi, 2006

[7] Caijun Shi, Yanzhhhong Wu, Chris Riefler, and Hugh Wang, "Characteristics and pozzolanic reactivity of glass powders", Cement and Concrete Research 35(2005)

[8] . V. M. Malhorta and P. K. Mehta, "High performance high volume fly ash concrete: materials, mixture 
proportioning, properties, construction practice and case histories", Ottawa, Canada, 2002.

[9] . M. L. D. Gougar, B. E. Scheetz and D. M. Roy Waste Management, 1996, 16(4), 295-303.

[10] . European standard EN 196-3: 1994: Method of Testing Cement. Part 3: Setting time and Soundness.

[11] . B. D. Bone, L. H. Barnard, D. I. Bortdman, P. J. Carey, C. D. Hills, H. M. Jones, C. L. MacLeod and M. Tyrer, "Review of scientific literature on the use of stabilization/solidification for the treatment of contamined soil, solid waste and sludges", Science Report SC 980003/SR2 - Environment agency U.K.

[12] .A. Bãdãnoiu, M. Georgescu and A. Zahanagiu, CANMET/ACI Conference 23-25 May 2007, Warsaw, Poland, Supplementary Papers Volume.

[13] Sh. Binod Kumar, Utilization of Copper Slag as Fine Aggregate in Cement Concrete, CRRI. 